\title{
Varieties of populism
}

\author{
Mark Tushnet*
}

(Received 31 December 2018; accepted 15 January 2019)

\begin{abstract}
Contemporary discussions of populism elide important distinctions between the ways in which populist leaders and movements respond to the failures of elites to follow through on the promises associated with international social welfare constitutionalism. After laying out the political economy of populisms' origins, this Article describes the relation between populisms and varieties of liberalism, and specifically the relation between populisms and judicial independence understood as a "veto point" occupied by the elites that populists challenge. It then distinguishes left-wing populisms' acceptance of the social welfare commitments of late twentieth century liberalism and its rejection of some settled constitutional arrangements that, in populists' views, obstruct the accomplishment of those commitments. It concludes with a description of the core ethnonationalism of right-wing populism, which sometimes contingently appears in leftwing populisms but is not one the latter's core components.
\end{abstract}

Keywords: right wing populism; left wing populism; international social welfare constitutionalism

\section{A. Introduction: identifying populisms}

I begin by describing two widespread approaches to identifying contemporary populism. ${ }^{1}$ The stipulative approach—common in journalistic accounts—attaches the label to regimes with charismatic leaders who claim to speak for "the people" and offer a rhetoric of opposition to "elites" of one or another sort. The definitional approach—taken by academics-offers general criteria by which populist regimes can be identified. The most common definitions include criteria like these: Politics is understood as setting "a morally pure and unified... people against elites who are deemed corrupt or in some way morally inferior" or as treating "only some people [as] really the people;" populists "split society into 'two homogenous and antagonistic groups: The pure people on the one end and the corrupt elite on the other,' and say they're guided by the "will of the people;"' populists "are not pluralist. They consider just one group ... 'the people'... legitimate."

These approaches treat populism as a mode of political activity, without specific substantive content. That content is provided by something else: Typically either some version of nationalistic neoliberalism or some version of a similarly nationalistic socialism. These are right-wing and

\footnotetext{
${ }^{*}$ William Nelson Cromwell Professor of Law, Harvard Law School. This essay is related to, and parts of it are drawn from Comparing Right-Wing and Left-Wing Populism, in Constitutional Democracy in Crisis? (Mark A. Graber, Sanford Levinson \& Mark Tushnet eds., 2018). Email: mtushnet@law.harvard.edu

${ }^{1}$ The term contemporary is important here. Populism has a long history, and it is almost certainly a mistake to think we can develop a useful category into which the Russian Narodniki of the nineteenth century, the People's Party of the late nineteenth century in the United States, Juan Peron of mid-twentieth century in Argentina, and Donald Trump all fit comfortably.

${ }^{2}$ Jan-Werner Müller, What Is Populism? (2016); Uri Friedman, What is a Populist?, The Atlantic (Feb. 27, 2017), https://www.theatlantic.com/international/archive/2017/02/what-is-populist-trump/516525/ (quoting and discussing CAS Mudde \& Cristobal Rovira Kaltwasser, Populism: A Very Short Introduction (2017)).
} 
left-wing populisms, respectively. Recent scholarly attention to populisms as such-along the dimension of "mode of political activity" - obscures differences along the dimension of substance. This article focuses on the latter dimension.

\section{B. Transformative "populism"}

Before addressing right and left-wing populism, though, I think it is important to identify something like a populism at the very foundations of democratic constitutionalism. This type of populism is, characteristic of, and perhaps limited to, contemporary forms of populism in Andean Latin America. Political movements that observers call populist in Ecuador and Bolivia sought and achieved what classical theorists of liberalism — such as Hannah Arendt,-called the transformation of subjects into citizens. ${ }^{3}$ Traditional elites there had excluded indigenous people from significant participation in politics both at local and national levels. Populist movements had the simple but profound goal of moving from exclusion to some degree of inclusion;"some degree" because the goal was to place indigenous people in no worse a position in Ecuador and Bolivia than were ordinary citizens in, for example, Western Europe. Having transformed subjects into citizens, populism could fall to one side, replaced by ordinary politics-which might of course include populisms with substantive content but could also include ordinary interest-group pluralist bargaining. 4

One important aspect of "transformative" populism is this: The transformation of subjects into ordinary citizens is an unequivocal good from the perspective of traditional liberalism. It is almost always accompanied by a reduction in the effective political power of existing elites; indeed, to some extent, the point of the transformation is precisely to reduce their power. Such a reduction is not problematic from liberalism's point of view; rather, it is one of the ordinary shifts in effective political power characteristic of well-functioning liberal polities.

Sometimes the transformation might be accompanied by a reduction in the formal power-and freedom - of existing elites. An example might be the imposition of constraints on press freedom imposed to ensure that the transformation not be undone by encouraging the mobilization of force against the new citizenry. Whether the transformation then is a gain for liberalism will depend upon the degree of impairment or reduction in formal freedom compared to the degree of enhancement of effective political power in the new citizenry. The key point here is that the reduction in formal freedom is not in itself enough to condemn the populist transformation as illiberal.

\section{The political economy of populisms' origins}

The substantive programs pursued by populists often flow from a diagnosis of a nation's current plight. Right and left-wing populists typically offer similar diagnoses. They begin with the programs offered by governing elites - for Western Europe after 1945, for central and eastern Europe after 1989, and for Latin America in the 1990s. Those programs were what I call international social welfare constitutionalism. National party systems were organized around competing policy agendas each of which was aimed at achieving that goal.

The social welfare component promised regularly increasing material well-being spread across all economic levels, with only occasional and temporary setbacks in mild recessions that elites could address through well-known macroeconomic techniques, coupled with a reasonably thick social safety network to help people weather those-and other predictable-setbacks. There

\footnotetext{
${ }^{3}$ Hannah Arendt, On Revolution (Penguin Classics 2006) (1963).

${ }^{4}$ I personally think it is unclear what course the Andean nations have taken; my sense is that Ecuador has moved a substantial way toward pluralist politics with Lenin Moreno's repudiation of Raul Correa's constitutional transformations, and that we will not know Bolivia's path until we see the outcome of forthcoming elections.
} 
would be a rough equality of sacrifice through taxes and burden-sharing in the ordinary course and when extraordinary events disrupted social functioning. There would also be a weak commitment to an even rougher equality of benefit constraining grossly disproportionate allocation of gains from economic growth.

The international component was the increasing integration of national economies into a global economy that would provide the resources to support the social welfare component. The traditional theory of international trade acknowledges that the substantial overall benefits flowing from such trade-evidenced, for example, by the substantial reduction in grinding poverty in China and India-can cause significant economic disruptions and pain elsewhere. Capital movement from the center to the periphery increases income in the periphery and lowers prices in the center, but throws some workers in the center out of jobs. International migration increases the incomes of those who move and, through remittances, of those who do not move, but similarly reduces employment opportunities previously available to workers in nations receiving immigrants. In principle, domestic political systems could address these matters. Job retraining programs and similar trade adjustment policies can allow workers adversely affected by international trade to obtain their share of the trade's benefits.

Finally, the constitutional component was a system of political organization that had the capacity to deliver all these elements of social welfare.

Contemporary populism emerged when, and because, political elites failed to follow through on international social welfare constitutionalism. On the constitutional level, domestic politics froze into patterns that made it impossible to respond with the flexibility needed to fulfill the promises of social welfare in dynamic economic conditions. In the United States, the phenomenon is called "gridlock." 5 Trade adjustment and job retraining policies, for example, were never adequate.

Political elites became corrupt both in the ordinary venal sense that they used their power to enhance their personal wealth, and in the political sense that they used political power to entrench themselves. Another form of corruption is that the political elites obtained the benefits of globalized trade and workers in the domestic economy displaced by that trade bore the burdenscontrary to the promise of equality in sharing burdens and benefits promised by international social-welfare cosmopolitanism. ${ }^{6}$

As political elites became more cosmopolitan, self-reproducing, insulated from economic stress, and self-satisfied, they became increasingly indifferent to fulfilling the social welfare promises they had made. Economic inequality increased, though that in itself was not inconsistent with international social welfare constitutionalism. More important, the promised increase in material well-being for citizens did not occur, or at least did not occur in the most readily discernible ways. Elites dealt with the disruptions occasioned by globalization either by doing nothing because of gridlock or by adopting austerity programs that left larger and larger gaps in the social safety net. On the constitutional level, legislative gridlock shifted policy-making power to the executive, which could govern through administrative law and decrees.

In short, the populist diagnosis was that elites had broken the promises they made. That diagnosis was largely correct. It gave a solid foundation to the anti-elitism that characterizes contemporary populism. Who precisely the elites were differed from nation to nation. In the global North, the elites who broke their promises were largely cosmopolitan neoliberals, whereas in the global South they were more traditional elites, used to getting their way in the face of opposition from domestic lower classes - and also cosmopolitan though to a lesser degree than in the global North.

\footnotetext{
${ }^{5}$ On some accounts of the international economic order, the internationalism that was part of the elite program produced gridlock and related phenomena, as parties differed over the degree to which their domestic economic programs should accommodate changes on the international economic scene.

${ }^{6} \mathrm{We}$ cannot ignore, though, that workers in other nations gained substantially from the globalized economy.
} 
Political entrepreneurs on the right and the left-outsiders to the political elites - noted an opportunity, and may have been especially attracted to executive office because of its increasing independence of legislatures constrained by gridlock. Sometimes they formed new political parties and sometimes they asserted themselves within existing parties by offering programs substantially outside the range of the elite consensus. What is common in contemporary populisms is an attack on failed and corrupt political elites. And we cannot understand those populisms, I believe, without acknowledging that the attack is to some substantial degree justified.

For the attacks to succeed-for the remedy actually to respond to the diagnosis- the failed political elites must be uprooted from their positions. Often this requires constitutional change because initial successes by populists can run up against "veto points" still occupied by political elites repudiated by the nation's citizens. A president might win a substantial victory only to face a legislature, or one house of a legislature, still controlled by those elites. Or, a president might win and carry the legislature along, only to find his or her programs thwarted by a constitutional court still controlled by the elites. Constitutional revision might be thought necessary to eliminate those "veto points" - by creating a unicameral legislature, for example, or sharply restricting the constitutional court's jurisdiction.

The implication for thinking about constitutionalism is straight-forward. Treating efforts to transform the courts as a strong point against populism—criticizing populists for assaulting judicial independence-and similar criticisms of other populist-supported constitutional changes may often be a defense of a failed status quo rather than a politically neutral defense of a central component of constitutionalism as such. Judicial independence should be undermined when it reproduces the failures of political elites to follow through on the promises of neoliberal internationalist constitutionalism. ${ }^{7}$

\section{Populisms and liberalisms}

I use the example of judicial reform and independence as a transition to a discussion of the relationship — if any-between liberalism and populism —or, again more precisely, the relationship between liberalisms and populisms. For, just as there are varieties of populism, there are varieties of liberalism. ${ }^{8}$ To count as liberal a constitutional system must meet some minimum requirements, but it can meet each one in numerous ways. Laws must be supported by popular consent elicited through reasonably reliable methods, for example. These include reasonably free and fair elections, of course, but also referenda and perhaps even formal consultative processes other than elections. Judges must have reasonable guarantees of independence from direct political control and from influences that strongly incline them to rule in ways favoring governing elites. Judges might be chosen by judicial nominating commissions or by elected officials, and once chosen their terms should be fixed in advance, and then they should be removable from office only for unprofessional conduct through processes with no more than a modest amount of direct political involvement.

Similarly, for every component essential to liberal constitutionalism, each component must be satisfied, but there are many ways of doing so. Importantly, changing from one institutional design for satisfying one component to another institutional design-from judicial selection by a nominating commission to judicial selection by executive officials-does not necessarily signal the abandonment of liberal constitutionalism. Liberal constitutionalism's institutional requirements,

\footnotetext{
${ }^{7}$ It might be that the costs of transforming the courts—and other institutions — are so substantial that the failed status quo is preferable to whatever might be achieved by a costly transformation. Populists might well disagree in light of their-again, often accurate- understanding of the costs of persisting with the status quo.

${ }^{8}$ For a more extensive treatment, see Mark Tushnet, Varieties of Liberalism, in HandBook OF COMPARATIVE Constitutional Change (Alkmene Fotiadou \& Xenophon Contiades eds., forthcoming).
} 
that is, are not terribly stringent. All that is required is that the institutions fall within a range of reasonable alternative possibilities.

Most if not all institutional changes implemented by contemporary populist regimes are, one by one, compatible with constitutional liberalism. This is shown by the fact that almost without exception for every institutional innovation or constitutional change implemented by a populist regime, we can find exactly the same institutional design in some unquestionably liberal polity. For example, rules against foreign support of domestic civil society organization, if not common, are not unknown in core liberal democracies-and Russian interference in elections has led to calls for strengthening those rules. Or, to take perhaps the most extreme example: Bolivia's 2009 constitution created a Plurinational Constitutional Tribunal, composed of judges chosen in national elections. No other constitutional tribunal in the world is elected, but high courts judges in most of the subnational units-states-of the United States are elected.

The qualification "one by one" in the preceding analysis is, however, quite important. Often constitutional provisions interact in the following way: An institution whose design places it near the margins of liberal constitutionalism, or perhaps on its own even illiberal, is offset by some other institution or by strong extraconstitutional norms. A system might fall outside the range of liberal constitutionalism if the problematic institution is retained and some of the offsetting institutions or norms are removed.

Controversies in Latin America about presidential term limits are an example. Before populist amendments, most Latin American constitutions limited presidents to a single term. They also concentrated law-making power in the presidency, for example by giving the president extensive power to make binding rules through decrees not effectively subject to legislative approval. The one-term limitation compensated for the concentration of executive power. Removing term limits, as has occurred in several Latin American nations-sometimes under populist pressure, sometimes by governing elites themselves - might push the system over the line separating liberal constitutionalism from authoritarianism, especially under the conditions, described earlier, that induce even greater concentration of power in the executive.

Determining whether populist-inspired constitutional changes are incompatible with liberal constitutionalism, then, will require a careful analysis of how the new system's institutions actually interact. And, unfortunately, no one appears to have come up with politically neutral methods for assessing such interactions yet. Too often disagreement with the right or left-wing policies pursued by populist regimes leads critics to decry as illiberal the institutional changes adopted so that the regimes can actually implement those policies. The same disagreement on the level of policy can lead critics to have an unsympathetic view of the institutional obstacles the regime's leaders face in implementing their programs. Instead, the critics impute authoritarian impulses to the regime's leaders. Of course, sometimes the changes will be illiberal and sometimes the leaders are incipient authoritarians, but not always.

There are undoubtedly strains of anti-liberalism - some devalorization of pluralist politics and the denial of equality among all citizens - in some right and left-wing populisms. Some of these strains are merely rhetorical. Sometimes a populist political leader will characterize all opposition as flowing from the interests of displaced elites to return to power, while at the same time acknowledging in practice that some opposition rests on real disagreement about the best course forward by treating that kind of opposition as within the bounds of political disagreement. Sometimes, though, the strains are truly illiberal, most notably of course in anti-Semitic and other racist expressions directed at citizens described as not members of the "real" nation.

\footnotetext{
${ }^{9}$ Here, I do not treat questions about the domestic constitutional status of immigrants and refugees, which are an important component of mostly right-wing populism in the global North. I think we need to distinguish between liberalism as a mode of organizing domestic politics and the claims of the modern international order. The former is concerned only with the status of citizens. Liberalism as a mode of organizing domestic politics tolerates quite a wide range of policies with respect to noncitizens, from nearly complete exclusion both from national politics and the national territory, to much more inclusive
} 
Still, extracting political theories from the statements of ambitious and entrepreneurial politicians is quite difficult. Neither Viktor Orbán nor Donald Trump offers a systematic political theory. Still, though we need not treat Viktor Orbán as offering such a theory when he described his preferred regime as illiberal-his emphasis on Hungary's Christian heritage at least borders on illiberalism. The concrete policies Orbán's government pursues —and similarly the concrete programs offered by all populist leaders-matter more than rhetoric. So, for example, though Orbán's rhetoric about Christianity is problematic from a liberal point of view, it is unclear that his government has actually done anything to implement policies that strongly exclude non-Christians from the Hungarian polity.

\section{E. Right- and left-wing populism}

With these qualifications about the relation between rhetoric and policy in mind, I turn to differences between right and left-wing populisms along the dimension of liberalism. Many writers have characterized right-wing populism as a movement of democracy_-"the people"-against all versions of liberalism considered as a political theory premised upon ideas about the inherent equality of all citizens. Further, many right-wing populist programs accumulate institutional changes that in the aggregate might move the regime outside the range of liberalism. The economic programs of right-wing populists are often entirely compatible with the free-market commitments associated with classical economic liberals. Part of their diagnosis of the domestic economy's ills, though, is sometimes that government policy extended social welfare guarantees "too broadly" - meaning, roughlyto those who were not truly part of the nation's organically defined people. Both in theory and often in practice, and with strong qualifications needed, right-wing populisms tend toward illiberalism.

Again, with the qualification that left-wing populist leaders are not systematic political theorists, left-wing populism seems rather different. Its economic program is to realize the socialwelfare constitutionalism that-neoliberal-political elites promised. Left-wing populists reject classical economic liberalism and neoliberalism as the means for realizing social-welfare constitutionalism, and even retain a residue of what used to be called international proletarian solidarity, which gives their program some internationalist commitments. They generally accept political liberalism's commitment to equality among citizens, as suggested by the fact that anti-immigrant sentiment appears to play a substantially smaller role in left than in right-wing populism.

Left-wing populists do propose some significant alterations in existing institutional arrangements, seeing those arrangements as giving their opponents too many veto points that they can-and do-use to impede the adoption of left-wing populist economic programs. Here in an odd way, they echo some observations made in the early and mid-twentieth century by reactionaries entirely opposed to the social-welfare state. Carl Schmitt and Friedrich Hayek argued, largely correctly, that realizing the promises of social-welfare constitutions-including now internationalist social-welfare constitutions-would necessarily interfere with classical liberal rights, for two reasons. First, as an economic matter, changes in markets and individual preferences would alter wealth distributions. To the extent that social-welfare liberalism is concerned about wide disparities in wealth, the state would have to intervene to adjust the new distribution. ${ }^{10}$

Second, politics provides the reason for placing social-welfare liberalism in tension with classical liberalism. Economic elites often overlap with political elites, and when they do not, economic elites are in a position to buy off the opposition corruptly. Left-wing populists—with

\footnotetext{
policies, even up to voting on an equal basis with citizens in some elections. The international human rights regime adds something to liberalism as a mode of organizing domestic politics, and in my view those who resist that regime are not for that reason alone antiliberal.

${ }^{10}$ Robert Nozick offered a famous illustration in his "Wilt Chamberlain" example: Assume that the distribution of wealth at time- 1 conforms to the social-welfare state's requirements. Some people will use some of their wealth to pay to see a star athlete, making him or her fabulously wealthy.
} 
right-wing populists, of course-believe that displacing the current political elites is essential to achieving their policy goals, which for left-wing populists include realizing the promises of social-welfare liberalism. Existing political and economic elites occupy strategic positions-again, the veto points - that need to be overcome by limiting their effective political power.

Doing so, though, might require not merely eliminating or weakening those veto points-for example by eliminating upper legislative chambers or reining in practices of constitutional and administrative review. Campaign finance regulations might be required, as might sharp limits on the contribution of nondomestic sources to domestic political parties and civil society organizations.

These constitutional adjustments might be described as altering existing understanding about the content of traditional first generation political rights. The question then arises, whether those changes are within the range of reasonable specifications of what liberalism permits? As suggested earlier, taken one by one, many of the changes are within that range. What though of the changes in the aggregate? Defenders of left-wing populism claim that even in the aggregate the changes do not move outside liberalism's parameters - though as with some versions of right-wing populism they might approach the boundary.

At this point, we face what might fairly be described as an empirical question. A classical test for whether a nation has made a transition from authoritarianism to democracy is that it has gone through two elections in which incumbents were displaced from office. What we have observed, mostly, is reelection without displacement. Yet, reelection in itself cannot tell us that a regime is entrenched against displacement, because voters might be expressing their uncoerced approval of the existing government. ${ }^{11}$

Assessing populism's staying power is therefore difficult. There undoubtedly has been a wave of populist politics in the first decades of the twenty-first century. What is less clear is whether that wave is simply part of the ebb and flow of ordinary politics, or a more enduring phenomenon. Some populists — such as Viktor Orbán—do seem to be in the process of transforming their regimes into authoritarian ones, but the ultimate outcome of the process is still unclear. ${ }^{12}$ Notably, the opposition to Orbán has still been able to mobilize large public demonstrations against his regime, something nearly impossible in authoritarian or even quasi-authoritarian regimes like Singapore.

That, though, need not be populism's inevitable course. Rafael Correa led a populist transformation in Ecuador. He restructured the judiciary, which gave him the ability to appoint many new judges. He supported formal and informal actions against media outlets that opposed him. He proposed to change the constitution to eliminate presidential term limits, which would have allowed him to remain in office indefinitely. Despite his seeming popularity, that proposal initially failed and when it resurfaced Correa had to promise not to take advantage of the new system. And then the populist transformation was reversed. Correa's designated successor Lenin Moreno turned on him and undid the constitutional changes Correa put in place. Whether other populist leaders will be able to institutionalize their charisma — as Max Weber would have put it-remains unclear.

Finally, I come to the nationalist components of right and left-wing populism. Right-wing populism's nationalism is ethnocentric, whereas left-wing populism's nationalism may be ethnocentric in immediate practice but need not be so in principle.

All forms of populism set "the people" against "the others," but who the others are can vary. Contemporary populism's diagnosis finds the source of domestic problems in an international political-economic order, and so "the others" also are found on the international plane. For present purposes, there are two candidates. The first are neoliberal elites who remain committed to-

\footnotetext{
${ }^{11}$ The best contemporary example here is not a populist regime, but the semi-authoritarian regime in Singapore, which regularly wins reasonably free and mostly fair elections by substantial margins that cannot be explained away as distortions of popular will by the governing party's manipulation of the election process.

${ }^{12} \mathrm{My}$ view of the relation between Hugo Chávez's populism and Venezuela's move, mostly under his successor Nicolás Maduro toward authoritarianism — and toward a failed state - is that much turned on differences in personality and political skill between Chávez and Maduro, and that had Chávez not died somewhat prematurely, Venezuela might — but might not— have followed a different path.
} 
and many of whom actually implemented-the failed policies of international social-welfare constitutionalism. ${ }^{13}$ These elites circulate easily across national borders, whether as investors, ex-patriates, or tourists. The second are economic - and other-migrants.

From a domestic perspective, the neoliberal elites are both domestic and foreign. Populists who counterpose "the people" to these elites can be ethnocentric. The domestic elites can be described as not truly of the people-perhaps, as in Latin American populisms, because they are the descendants of foreign invaders, or perhaps, as in anti-Semitic populisms, because they either are Jews or are in thrall to Jews. Having placed neoliberal elites outside "the people" because they have transnational ties, these populists readily, though perhaps not necessarily, similarly place immigrants outside the people. This may be something like an elective affinity. Certainly many populist political leaders find it helpful to political success to lump immigrants with "the elites" who control the economy. This seems to be the general path taken by right-wing populists.

Left-wing populists also counterpose neoliberal elites to "the people." But, for them, the national or transnational affiliations of those elites are not intrinsic to their role in causing domestic problems. Indeed, some left-wing populist leaders more or less expressly treat these elites as primarily non-domestic, focusing for example on the role of international financial institutions_-"the Troika," in some European settings-in causing domestic problems. ${ }^{14}$ In the left-wing account, the immigrant community might be described as orthogonal to populism's main concerns. Left-wing populists sometimes basically ignore immigrants, sometimes treat them as victims of the failed neoliberal project, and sometimes treat immigrants as part of "the other" as well. The key point, though, is that treating immigrants as "the other" is incidental to left-wing populism, not even a matter of elective affinity. To the extent that they divide the world into a favored "people" and a disfavored "other," left-wing populisms tend to define the categories with reference to something like economic class rather than with reference to nationalism.

The differences between right and left-wing populisms play out in policies with constitutional implications. Left-wing populists often support restrictions on capital movement away from their nations, for example sometimes by rejecting austerity programs and adopting budgets with deficits that can only be financed by domestic capital at home. Such restrictions can run up against the protections that classical constitutions give private property. And, as noted, achieving significant redistribution of wealth domestically may require restrictions on elite political activity-such as restrictions on elite financing of political parties and even of civil society organizations. Finally, right-wing populisms' ethnonationalism of course bumps up against domestic guarantees of equality among citizens even if liberal constitutionalism allows substantially worse treatment of immigrants than of citizens.

\section{F. Conclusion}

Attention to populist politics' substantive dimension might generate some thoughts about whether populist politics will endure. Perhaps, for example, the ethnonationalism associated with right-wing populist politics is more, or less, susceptible to institutionalization than the nominally internationalist socialism associated with left-wing populist politics. Whatever the answer, it seems better to keep both dimensions of populism - as a mode of action and as a vehicle for substantive policies-in mind when we talk about contemporary populism.

\footnotetext{
${ }^{13}$ We might take "\#Davos" as the hashtag for this group.

${ }^{14} \mathrm{By}$ focusing on these institutions, though, these leaders might deliberately or inadvertently take advantage of traditional anti-Semitic images of evil Jewish bankers.
}

Cite this article: Tushnet M (2019). Varieties of populism. German Law Journal 20, 382-389. https://doi.org/10.1017/ glj.2019.27 